\title{
低流速下における垂直軸揚力型水車の利用手法 UTILIZATION OF VERTICAL-AXIS LIFT-TYPE HYDRO TURBINE UNDER A LOW FLOW CONDITION
}

\author{
中矢哲郎1・桐博英2 ・安瀬地一作3 \\ Tetsuo NAKAYA， Hirohide KIRI, and Issaku AZETI

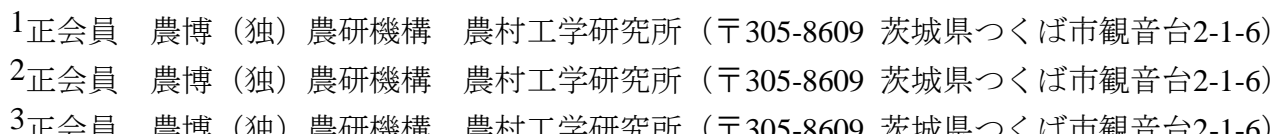

The hydraulic and output characteristics of a vertical-axis lift-type Darrieus water wheel were examined using an experimental hydraulic model to determine effective methods for utilizing hydraulic power under a low velocity flow of about $1 \mathrm{~m} / \mathrm{s}$ in an irrigation canal. Our results indicate that despite the low velocity of this flow, water wheel efficiency was improved by installation of a spur dike that raised the water level and increased pressure. Moreover, useful energy was effectively obtained by appropriately adjusting the ratio of the total area of a braid to that of the passage feeding the water wheel .

Key Words : Flow energy, Water turbine, Darrieus-type, Small-scall Hydro-power

\section{1.はじめに}

農村地域における既存の農業水利施設を利用した小水 力発電は, 大規模な地形改変を必要としない再生可能エ ネルギー源として，これまで落差工や急流工に設置され てきた。一方，水路における流水エネルギーはこれまで 小水力発電の対象にならず, ほとんど未利用で残されて いる. その原因として，得られる電力が数 $\mathrm{k}$ W以下とな り，売電収入が見込めないことがあげられる。しかし小 規模の電源でも，農村地域においては，1kWhの充電で 走行可能な電気自動車や，水路の水管理システムの電源， 災害時の非常用電源など多くの使用用途が存在する. よって流水エネルギーを用いた簡便に設置ができ，可搬 型でかつ低コストな発電装置の開発が望まれる.

流水エネルギーによる小型水力発電に関して，クロス フロー水車と下掛け水車を組み合わせ，水車内に自由水 面を有する開放型の水車や1)，並進翼水車による流水工 ネルギーの利用に関する研究が進められているが2， ど ちらも水路幅全体を仕切る為にやや大掛かりになる傾向 にある. 小規模のものになるとプロペラ式があり ${ }^{3)}$ ，最 大で100Wの出力が得られ普及しているものの，農業用水 路が対象とする $1 \mathrm{~m} / \mathrm{s}$ 程度では低出力となり，農業用水路 には不適である.
近年は垂直軸型の発電装置が，風力発電の分野で進ん でいる. 水力でも潮流を対象に開発が進んでいる。また 垂直軸タービンの中で揚力を利用するタイプのものは抗 力を利用するものと比較するとかなり効率が良いことが 知られており，構造が簡単なためメンテナンスコストが 低廉となる、また，垂直軸であるため流向に依存しない などの利点を有している.このような利点は，農業用水 路の流水や超低落差下の利用に適するが，発電にはほと んど利用されていない状況にある.

\section{2. 研究の目的}

以上の背景のもと，本研究では，まず農業用水路の平 均的な流速である $1 \mathrm{~m} / \mathrm{s}$ 以下の低流速下における垂直軸水 車の出力特性を明らかにする，そして低流速下で水制な どの障害物を設置することによる圧力エネルギーの上昇 が，流水エネルギーの利用効率に及ぼす影響を明らかに する.

さらに実スケールを想定した発電試験により，流水か ら実際に得られる電力を算定し，農業用水路を想定した 流水下における小水力発電利用としての有効性について 検証を行った. 


\section{3. 垂直軸水車の出力特性と水理特性}

\section{（1）垂直軸水車の出力特性}

垂直軸タービンの開発が進んでいる風車の事例にあて はめて出力特性を検討する. ここで，風車の機能評価で 用いられるパワー係数 (流体の中から風車を利用して取 り出すことのできるパワーの割合）とトルク係数（流体 から得られるトルクの割合）を指標に用いる．抗力型風 車は単純な仕組みで風が単にロータの羽根や風杯をおす ようになっている. パワー係数が小さいが，トルク係数 は大きく，自己起動するため揚水や製粉のような機械的 な仕事をするのに適している. 揚力型風車は駆動力に揚 力をもちいる. 風車のブレード先端速度と流入流速の比 である周速比が大きくなるために，高回転が得られる． ここで周速比は次式で表せる.

$$
\lambda=\frac{\Omega R}{V_{\infty}}=\frac{2 \pi R n}{V_{\infty}}
$$

ここで， $R$ :ロータ半径 $(\mathrm{m}) ， \Omega$ : ロータの回転角速 度 $(\mathrm{rad} / \mathrm{s}), n$ : 風車回転数, $V_{\infty}$ : 流入風速, である.

揚力型風車は，パワー係数は大きいが，トルク係数は 低く，発電用に適する特性を有している．上って今回は 垂直軸水車として揚力型のダリウス水車を選定する.

\section{（2）垂直軸水車の水理特性}

流水利用型の水車は, 水平軸の開放型下掛け水車式と ダリウス水車などの垂直軸型に分けられる．いずれにお いても，流水エネルギーを効率的に取り出寸ための工夫 がなされている. 下掛け水車式については堰上げ効果を 利用した流水利用の出力特性について検討されている 1). 垂直軸水車のダリウス型に関しては流速エネルギー を有効に取り出寸ための, 集水ダクトにより流速を増加 させる方法が検討されている4).

実際に流水エネルギーを水頭に換算すると，例えば流 速 $1 \mathrm{~m} / \mathrm{s}$ でも $5 \mathrm{~cm}$ 程度であり, 圧力エネルギーや位置エネ ルギーを取り出寸方が大きなエネルギーを簡易に得られ る. 流水エネルギーを取り出す場合，たとえば水位差を $10 \mathrm{~cm}$ とことで，流速 $2 \mathrm{~m} / \mathrm{s}$ に相当するエネルギーを取

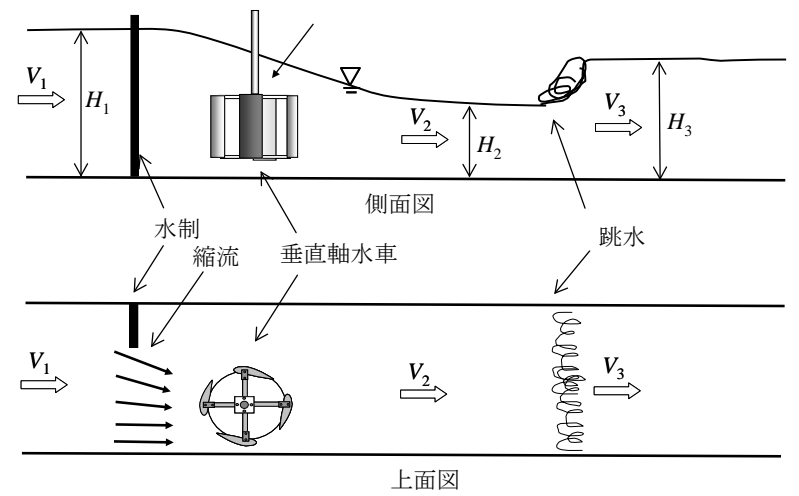

図-1＼cjkstart垂直軸水車周辺の流れの概要
り出すことが可能になる. よって, 今回, 水車前後の圧 力差を強制的に発生させ，速度エネルギーが得られにく い低流速下でも効率的に揚力型水車により発電を行う手 法に関して検討を行う。

この流水中に水位差を強制的に起こす方法として，今 回は図-1のように，水路を横断する水制を設置すること で強制的に堰上げを行い圧力差を生じさせることを検討 する. 水制は大掛かりな工事なしに水路への設置が可能 である．また，農業用水路においてこうした圧力エネル ギーを取り出す場合, 通水時の溢水に注意を要するが, 余裕高の範囲を活用することで，導入の可能性が高くな る.ここで余裕高とは，一時的に生ずる高水位等に対 し, 水路の安全を保つために設定される計画水位より上 の高さである. この水制による水位の堰上げにより, 流 水エネルギーだけでなく, 圧力エネルギーも有効に取り 出すことが可能となる. この圧力差を考慮した水車の出 力P $(\mathrm{W})$ は, 次式で表せる.

$P=\rho g Q H_{e}$

ここで, $\rho:$ 水の密度 $\left(\mathrm{kg} / \mathrm{m}^{3}\right), Q$ : 流量 $\left(\mathrm{m}^{3} / \mathrm{s}\right)$, $H_{e}$ : 有効落差 $(\mathrm{m})$, である. 有効落差は図-1より圧力エ ネルギーの差と速度エネルギーの差の合計となる.

$H_{e}=\frac{P_{1}}{\rho g}-\frac{P_{2}}{\rho g}+\frac{V_{1}^{2}}{2 g}-\frac{V_{2}^{2}}{2 g}$

ここで, $P_{1}=\rho g H_{1}, P_{2}=\rho g H_{2}$, である. 下流水深に $H_{3}$ ではなく $H_{2}$ としたのは， $H_{3}$ とすると, 跳水によるエネ ルギ一損失を有効落差として見積もり，入力として過小 評価することになるためである. また出力効率は次式で 算定する.

$\eta=W_{0} / P$

ここで, $\eta$ : 出力効率, $W_{o}$ : 水車の軸出力（回転トルク $\times$ 回転角速度），である.

\section{4. 発電装置の製作}

\section{(1) 水車の選定}

水車には揚力型の垂直軸水車である，ダリウス型を採 用した. ダリウス水車形状の概要を図-2に示寸．水車の
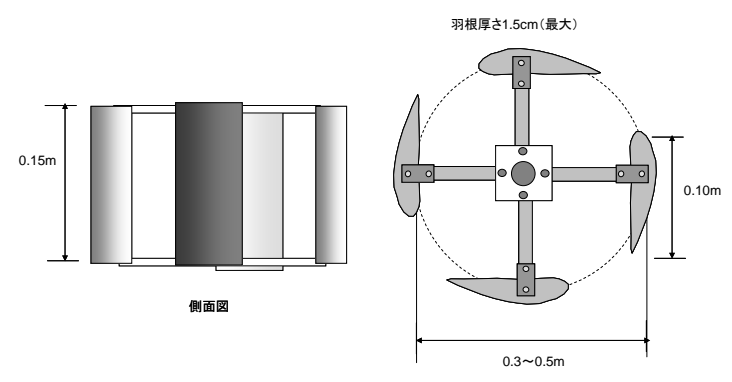

上面图

図-2 ダリウス水車の形状 


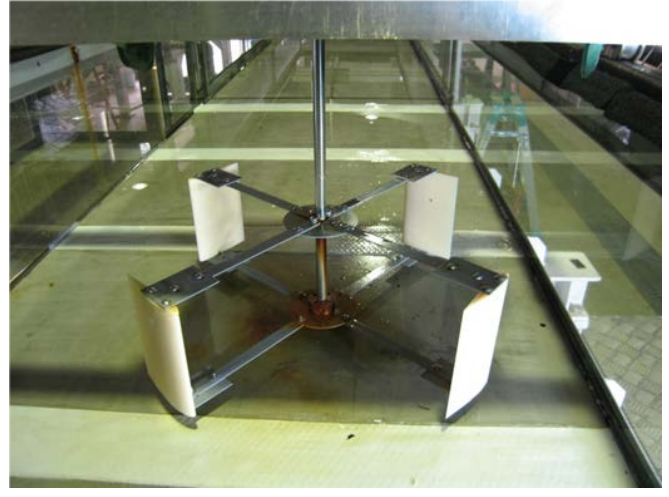

写真-1 ダリウス水車の形状（水車径 $50 \mathrm{~cm}$ ）

規模は $90 \mathrm{~cm}$ 水路内に入る大きさで，圧力差を生じさせ るための障害物を設置するスペースを確保できる大きさ の， $50 \mathrm{~cm}$ と $30 \mathrm{~cm}$ 二種類を設定した，羽根数は 4 枚に設 定した. 水車径 $50 \mathrm{~cm}$ 場合の水車形状を写真-1に示す.

\section{（2）＼cjkstart羽根形状の設定}

羽の断面はNACA0018と呼ばれる, 航空機の断面で採 用されているものを用いた. 羽はABS樹脂で作成した. この断面形状により，垂直軸であっても反転時に大きな 逆向きの抗力がはたらかずに, 高い水車の周速が得られ るようになる.

\section{（3） ソリィディティの設定}

ソリディティは，風車の掃過面積に対するブレードの全 投影面積の比であり，ダリウス型水車の効率に大きく影 響を及ぼすパラメータである.ここでの掃過面積は水車 回転軸に垂直な面への投影を意味している. この水車の ソリディティと周速比も強い相関をもっている. ソリ ディティと風車効率の関係については, ソリディティが 大きい場合は，風車を通過する気流が急激に減速される ために, トルクが低下し効率が落ち，また小さすぎる場 合は，ブレード面積が小さくなるために大きなトルクを 得ることができず効率が高くならないことが知られてい る5). よって, ダリウス水車の効率を上げるには最適な ソリディティの值を見つけることが重要になる.

ダリウス型水車のソリディティは次式で算定する.

$\sigma=\frac{Z C}{2 \pi R}$

ここで, $\sigma:$ ソリディティ, $Z:$ ブレード枚数, $C:$ ブ レード弦長 $(\mathrm{m}), R$ : ロータ半径 $(\mathrm{m})$, である.

今回は，水車径を $0.3 \mathrm{~m} ， 0.5 \mathrm{~m}$ とた 2 種類のロータを 作成したため，それぞれソリディティは，0.42，0.25と なる. ソリディティ值毎の出力係数に及ぼすパラメータ

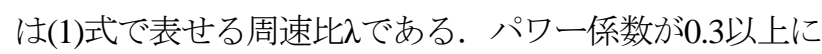
なる周速比の範囲（最適範囲）は, 水車径が大きい $\sigma$

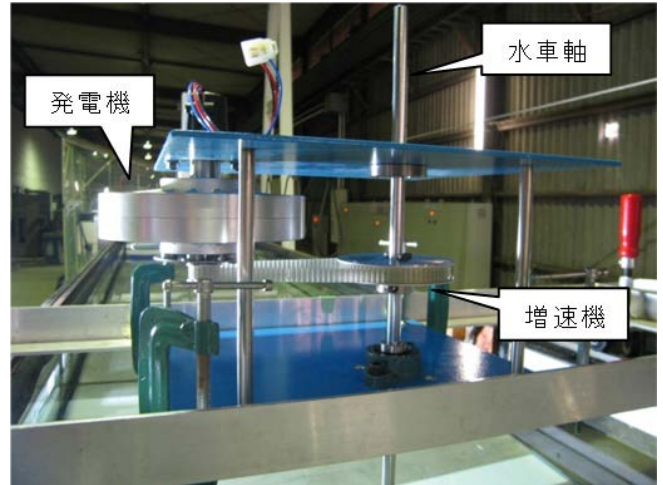

写真-2 発電装置の概要

$=0.2$ の場合, 概ね $\lambda=3 \sim 7$ 範囲で $\lambda=6.0$ 付近にピーク がある. 水車径が小さい $\sigma=0.4$ では, $\lambda=2 \sim 4$ 付近で $\lambda$ $=3.0$ 付近にピークがある ${ }^{5}$. よって高ソリディティの場 合(水車径 $30 \mathrm{~cm})$ は, 低周速域で高出力が得られる可能性 があるがその最適範囲が狭く, 低ソリディティの場合

（水車径 $50 \mathrm{~cm}$ ）は出力のピークは高周速比側にあるが, その最適範囲が広いという特徴がある。

\section{（4） 発電装置の製作}

発電装置の概要を写真-2に示す．水車に上部まで伸び た軸を設けた. 水車の回転は 4 倍増速機により回転数を あげた後に発電機を回す仕組みである. 発電機からは 3 相交流で出力されたあと, ブリッジダイオードにより直 流に変換し出力する. 本装置は水車羽部分が約 $2 \mathrm{~kg}$, そ の他の装置の部分が $10 \mathrm{~kg}$ であり, 大人 1 人で持ち運ぶこ とが可能である. 発電機は，モーター内部に鉄心がなく， トルクの少ない，直径 $20 \mathrm{~cm}$ 厚さ $3 \mathrm{~cm}$ の小型のコアレス モーターを採用した（株式会社スカイ電子, SKYHR200）。この発電機は，低回転で大きな出力を得るこ とができ，低回転の垂直軸水車の発電モーターとして適 している.
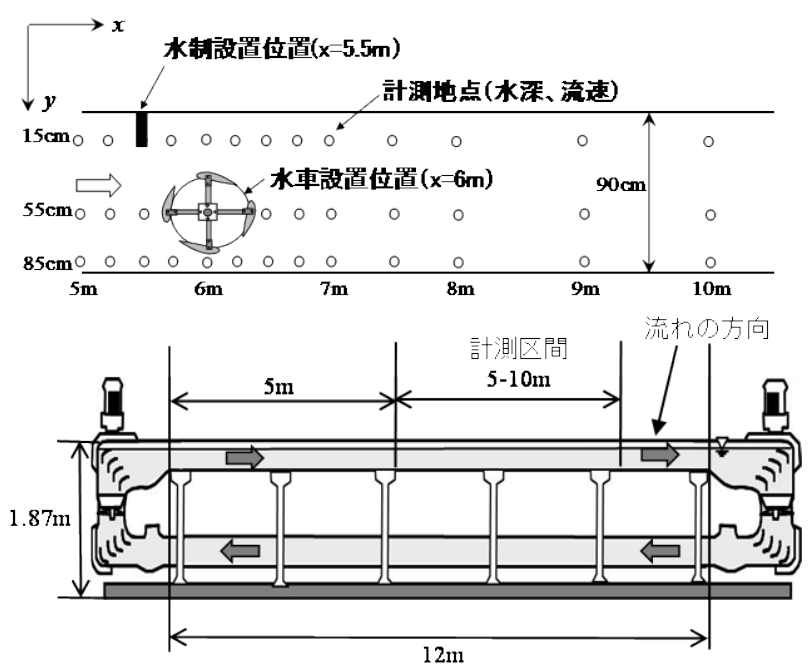

図-3 実験水路の概要 


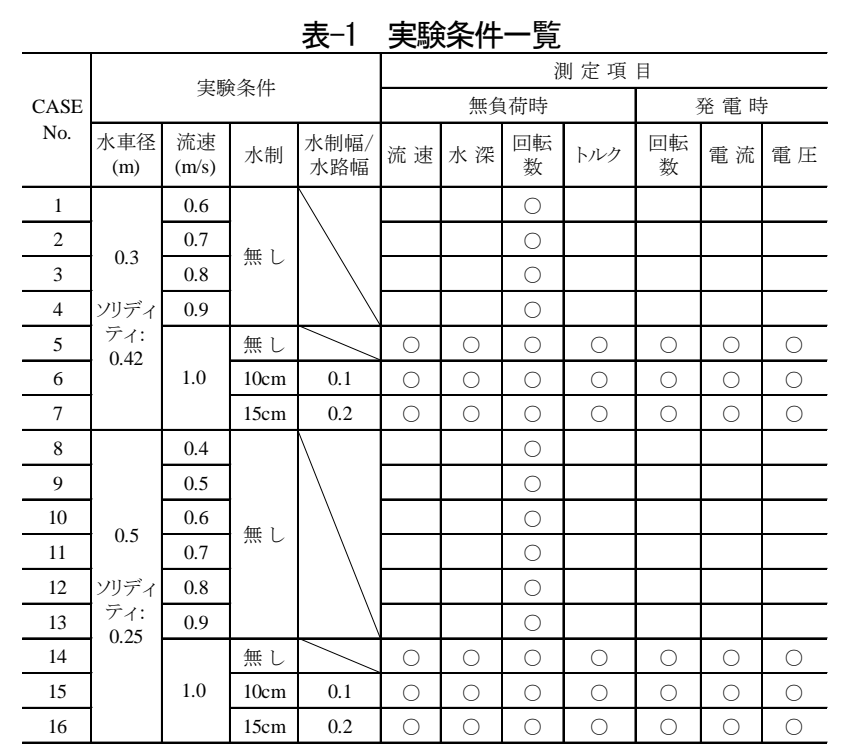

\section{5. 水理模型実験の方法}

\section{（1）実験の方法}

実験には，農村工学研究所風洞造浪実験棟内の図-3に 示す幅 $90 \mathrm{~cm}$, 長さ $12 \mathrm{~m}$ の回流水槽を用いた。計測は, 図-3にある点において，流速，水位を測定し，農業用水 路で想定される流速 $1 \mathrm{~m} / \mathrm{s}$ 以下の流況での水車周辺の流 況, 水理特性, 出力特性を把握した. 流速は 6 割水深点 を計測した。ここで設定した流速 $1 \mathrm{~m} / \mathrm{s}$ は水路内に障害物 がない場合に生じる実験水路の最大流速である.

流れの条件としては，流速 $1 \mathrm{~m} / \mathrm{s} か ら 0.1 \mathrm{~m} / \mathrm{s}$ 毎で流速を 下げて低流速条件を設定した。さらに $1.0 \mathrm{~m} / \mathrm{s} の$ 流水エネ ルギーから効率的にエネルギーを得る方法として，図-3 に示寸水車前面の位置に水制を設置し，流速エネルギー のほかに堰上げにより生じる圧力エネルギーも取り出す ことを試みた. 水制の設置幅は $10 \mathrm{~cm}$ と $15 \mathrm{~cm}$ の種類と し，水制高は水面より上の長さとし非越流状態とした.

モーターの回転数の測定には, 非接触型ハンディタコ メータ（株式会社小野測器 HT-4200）を用いた。電力 は直流回路にセメント抵抗を負荷として与え，電流電圧 值を測定することで算出した.

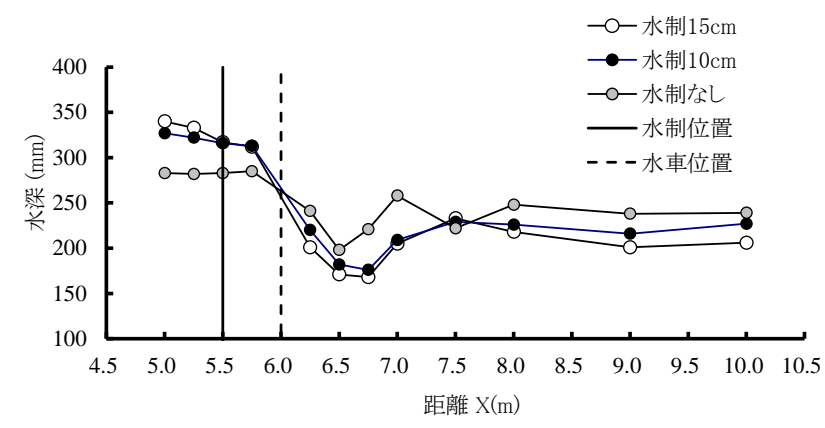

図-4 水車近傍の水位（Case14, 15, 16)

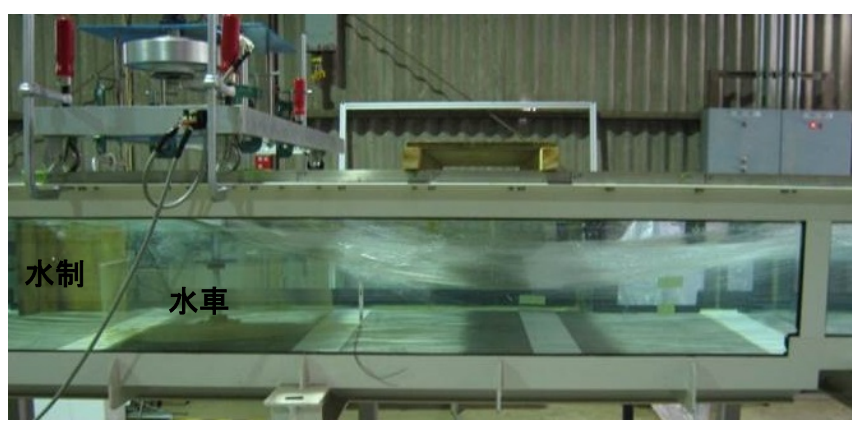

写真-3 水車近傍の流況 (Case16)

\section{（2）実験条件}

実験ケースを表-1に示寸，設定する流速は，水路内に 障害物がない場合に発生する最大流速值である．2 種類 の水車径において, 水車の回転が始まる流速から $0.1 \mathrm{~m} / \mathrm{s}$

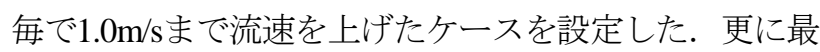

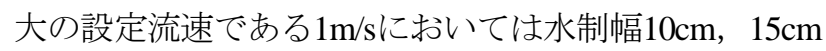
を設置することで，圧力エネルギーの上昇効果の実験 ケースを設定した。発電機の特性から，100rpm以上が 最低の回転数であるため, 計測の対象とするのは無負荷 時で100回転以上を得られた，流速 $1 \mathrm{~m} / \mathrm{s}$ 下で，水制な し，水制幅 $10 \mathrm{~cm}$ ，水制 $15 \mathrm{~cm}$ のase5〜 7, およびCase14 〜16を重点的に行った.

\section{6. 実験結果及び考察}

\section{（1）水車周辺の流況}

流速 $1 \mathrm{~m} / \mathrm{s}$ ，水制設置幅 $15 \mathrm{~cm}$ で最も高い回転数が得ら れたCase16の水車周辺の流況を写真-3に示す. 水車と水 制の抵抗により上流側に堰上げが生じており，水車下流 部で水位低下が生じている，さらに下流になると下流端 の水位の影響て跳水が生じるため再び水位が上昇してい る. なお，全ケースで水車はほぼ水没している状況にあ る.

Case14～16における水車近傍水位の変化を図-4に示 す. 水制を設置することで上流の堰上げが大きくなり， 下流の水位低下が生じ，上下流の水位差が大きくなって

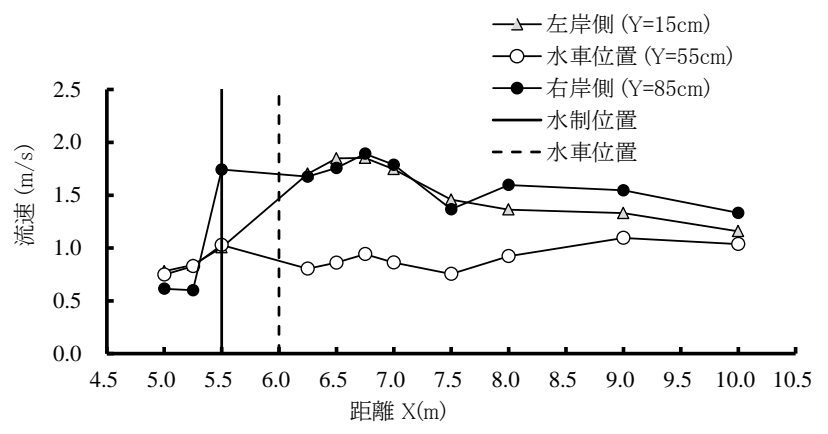

図-5 水車近傍の流速（Case16） 
表-2 水車効率一覧

\begin{tabular}{|c|c|c|c|c|c|c|c|c|c|c|}
\hline $\begin{array}{l}\text { Case } \\
\text { No. }\end{array}$ & $\begin{array}{c}\text { 水車径 } \\
(\mathrm{m})\end{array}$ & $\begin{array}{l}\text { 水制幅/ } \\
\text { 水路幅 }\end{array}$ & $\begin{array}{l}\text { 流速 } \\
(\mathrm{m} / \mathrm{s})\end{array}$ & $\begin{array}{c}\text { 回転数 } \\
(\mathrm{rpm})\end{array}$ & $\begin{array}{l}\text { トルク } \\
(N \cdot m)\end{array}$ & $\begin{array}{c}\text { 水車出力 } \\
W_{o}\end{array}$ & $\begin{array}{c}\rho g H e Q \\
P\end{array}$ & $\begin{array}{l}\text { 出力効率 } \\
\eta(W o / P)\end{array}$ & $\begin{array}{c}\text { 発電時回転数 } \\
\text { (rpm) }\end{array}$ & $\begin{array}{c}\text { 発電機最大出力 } \\
W_{e}\end{array}$ \\
\hline 1 & \multirow{7}{*}{$\begin{array}{c}0.3 \\
\text { ソリディ } \\
\text { ティ:0.42 }\end{array}$} & & 0.6 & 0 & - & - & - & - & - & - \\
\hline 2 & & & 0.7 & 37 & - & - & - & - & - & - \\
\hline 3 & & & 0.8 & 56 & - & - & - & - & - & - \\
\hline 4 & & & 0.9 & 95 & - & - & - & - & - & - \\
\hline 5 & & & \multirow{3}{*}{1.0} & 103 & 0.52 & 1.40 & 11.59 & 0.12 & - & - \\
\hline 6 & & 0.1 & & 271 & 0.68 & 4.82 & 19.23 & 0.25 & - & - \\
\hline 7 & & 0.2 & & 300 & 0.86 & 6.75 & 25.14 & 0.27 & - & - \\
\hline 8 & \multirow{9}{*}{$\begin{array}{c}0.5 \\
\text { ソリディ } \\
\text { ティ:0.25 }\end{array}$} & & 0.4 & 0 & - & - & - & - & - & - \\
\hline 9 & & & 0.5 & 30以下 & - & - & - & - & - & - \\
\hline 10 & & & 0.6 & 30以下 & - & - & - & - & - & - \\
\hline 11 & & & 0.7 & 30以下 & - & - & - & - & - & - \\
\hline 12 & & & 0.8 & 37 & - & - & - & - & - & - \\
\hline 13 & & & 0.9 & 57 & - & - & - & - & - & - \\
\hline 14 & & & \multirow{3}{*}{1.0} & 340 & 0.72 & 6.41 & 14.97 & 0.43 & 280 & 3.00 \\
\hline 15 & & 0.1 & & 377 & 1.04 & 10.26 & 29.62 & 0.35 & 316 & 5.12 \\
\hline 16 & & 0.2 & & 396 & 1.32 & 13.68 & 38.00 & 0.36 & 300 & 6.40 \\
\hline
\end{tabular}

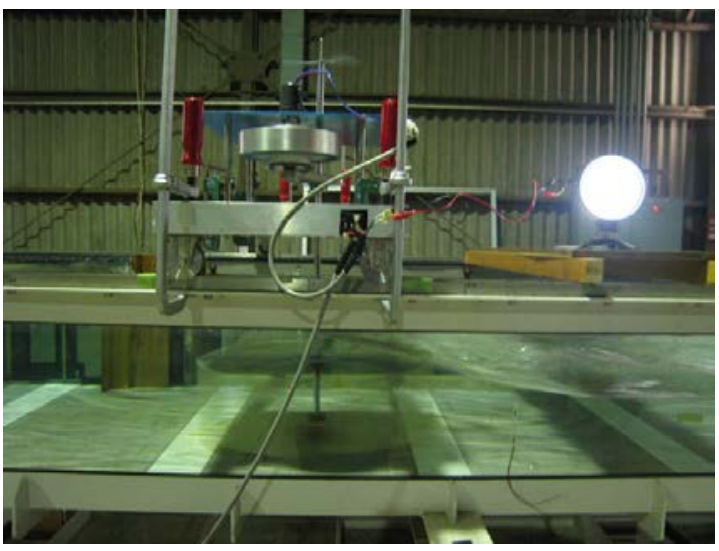

写真-4 流水型水車の発電状況 (Case16, 2W出力のLEDライト)

いる．水制幅が大きくなり，抵抗が大きくなるほどこの 水位差は大きくなっており，より多くのエネルギーを得 られていることを示している. 図-5のCase16における流 速の変化を見ると，水車上流は堰上げにより一様に流速 は低下している。流においては水車位置のラインは流 速が低下したままであるが，水車周辺では流速が上昇し ている．このことは水車が速度エネルギーを消費してい ることを示している. こうした水車上下流の水位差と流 速の差から式(2)により有效落差 $H_{e}$ を算定することが可 能となる.

\section{（2）水車の出力特性}

表-2に水車の出力一覧を示寸．水車径 $0.3 \mathrm{~m}$ のときは 回転が始まるのは流速が $0.7 \mathrm{~m} / \mathrm{s}$ 以上であり, 水車径 0.5 の ときは回転が始まるのは $0.5 \mathrm{~m} / \mathrm{s}$ であり, 水車径が大きく ソリディティが小さい方が低流速で高回転が得られてい
る. 流速を上げた条件でもソリディティが小さい方が大 きな回転数が得られている. なお両水車径において，回 転しているにも関わらずトルクが算出できていないの ケースは, 回転数がトルク計の下限值を下回まわり計測 不能であったためである.

流速1m/s時のCase5〜 7，14～16を見ると，全て100rpm 以上になっており，水制幅を大きくし，堰上げを大きく するほど大きな回転数とトルクを得ることができてい る. この時の回転数やトルクは水車径 $50 \mathrm{~cm}$ でソリディ ティが小さいケースが大きくなっている.

水車の出力は同じ流速では水車径 $50 \mathrm{~cm}$ のースの方 が2倍以上大きくなっている. 同じ水理条件であって も，水車径により規定されるソリディティが水車の出力 に重要なパラメータであることがわかる，今回は，低ソ リディティで掃過面積が小さい方で高い水車出力を得ら れた. この原因は4-(3)で示した, ソリディティ毎の周速 比とパワー係数の関係から推定できる. $\sigma=0.42 の$ 場 合，低周速比で高出力を得られるが，今回は周速比が低 寸ぎて（ $\lambda=0.97 ）$ ，高出力域に到達できなかったこと

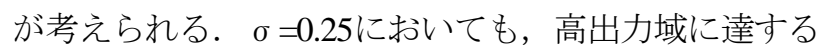
周速比は得られていないが $(\lambda=2.5)$ ，周速比に対する 高出力域が広いために出力が大きくなったと考えられ る．今後，周速比を上げるには，水制設置幅をより大き くし，流速を上げるか，水車の羽根形状や材質などロー 夕そのものの性能を上げ，大きな回転数を得ることが必 要である. 周速比が上がれば水車径の小さく高ソリディ ティ下での出力が向上し，より経済的な水車の設計が可 能になる. 
発電状況を見ると，発電ができたのはCase14〜16の出 力が大きかった3ケースである．発電時は発電抵抗によ り回転数が減少するが，最大で6Wの発電ができた。 こ のときの2W出力LEDの発電状況を写真-4に示寸. 6Wで あっても系統電力につなげない場合であれば，水管理シ ステムの供給電源や, 堰, ゲート等水利構造物の制御シ ステムの電源など多くの用途が存在するため, 小水力発 電装置として有効であるといえる.

\section{7. 結論}

農業用水路で想定される流速 $1 \mathrm{~m} / \mathrm{s}$ 程度の流況で水力を 得るために, 垂直軸揚力型のダリウス水車の出力特性, 発電状況を水理模型実験より把握した.

その結果，低流速下であっても水制設置による堰上げ による圧力エネルギーの増大により水車効率を上昇させ ることができることがわかった.

また, 今回の水理条件では, 低周速域における出力が 大きい高ソリディティ（水車の掃過面積に対するブレ一 ドの全投影面積の比）值より，低周速比での出力は小さ
いが周速比に対する高出力域が広い低ソリディティ值の 場合に有効に流水エネルギーを得ることができた. 今後 低周速域での出力効率を上げるには，水制設置幅を拡げ 流速を上げるか，ダリウス水車の羽根形状や材質などの 性能を上げ，水車の回転数を上げる必要がある.

\section{参考文献}

1) 上田達己，後藤眞宏，桐博英，浪平篤，滝口孝明，廣瀬裕 一: 独立運転するマイクロ水力発電の経済・環境影響評価, 水土の知, No.81(2), pp.97-100, 2013.

2) 後藤眞宏, 内田隆志，加藤信介，岡本将之，大木啓司，長 谷川大祐, 高木強治, 浪平篤: 緩勾配水路における小水力 発電技術の開発，水土の知， No.78(8)，pp.665-668，2010.

3) David Sharman:Generating interest under water, International Water Power \& Dam construction, Vol.61-2,pp.919-924, 2009.

4) 古川明徳, 大熊九州男 : ダリウス形ランナによる超低落差 水力の有効利用, ターボ機械, No.30, pp.14-19, 2002.

5)関 和市, 牛山 泉: 垂直軸風車, パワー社, pp.171-174, 2008.

(2014. 9. 30受付) 